\title{
LANGUAGE EDUCATION IN THE FIELD OF SYNTAX AND STYLISTICS (BASED ON THE MATERIAL OF CONJUNCTIONLESS COMPLEX SENTENCES IN THE MARI LANGUAGE)
}

\author{
Galina L. Sokolova', Anna L. Kolyago ${ }^{2 \star}$ \\ ${ }^{1}$ Assos. Prof., Mari State University, Russia, askgalinasokol@mail.ru \\ ${ }^{2}$ Assos. Prof., Mari State University, Russia, kolyago@yandex.ru \\ ${ }^{*}$ Corresponding author
}

\begin{abstract}
One of the main goals of language teaching is the formation of a language personality. Language personality, in turn, is formed within the framework of language education. Knowledge of the language, the peculiarities of its structure, functioning, as well as knowledge of language norms in the field of phonetics, morphology, syntax and stylistics, and the ability to use them in the practice of oral and written speech communication, is an indicator that a language personality is formed. Knowledge of the syntactic foundations of the language, which implies the ability to build phrases and sentences correctly and the ability to perform oral and written communication on the basis of syntax, is the highest level of language education. The ability to express one's thoughts using complex sentences indicates an intellectually developed linguistic personality. Knowledge of the theoretical foundations of the native language enriches the native speaker and creates favorable prerequisites for mastering other languages. In the modern Mari language, there are two types of complex sentences: conjunctive and conjunctionless. Both types of sentences have a rich stylistic potential. If conjunctive complex sentences use different types of conjunctions for imagery and expressiveness, conjunctionless complex sentences have to resort for this purpose to such means as intonation, modal-temporal forms of verbs, ellipse, etc. In our study, we will focus on the stylistic expressiveness of conjunctionless complex sentences in comparison with conjunctive ones. Knowledge of the theoretical foundations of syntax and stylistics will indicate that the language personality is formed and has mastered language competencies, which is one of the main goals of language education.
\end{abstract}

Keywords: language and education; language personality, language competency; Mari language; syntax; stylistics; conjunctionless complex sentence; expressivity; emotionality.

\section{INTRODUCTION}

In the Finno-Ugric proto-language, from which the Mari language was formed, there were no complex sentences. A complex thought was expressed in simple sentences, following one after the other. Complex sentences began to appear in some Finno-Ugric languages. The system of complex sentences in Finnish and Hungarian is considered to be the most developed. In the Mari language the most common are conjunctionless complex sentences. The conjunctive complex sentences developed to a greater extent, under the influence of the Russian language, as the Mari language researchers admit. At the same time, both borrowed from the Russian language and native Mari conjunctions are used to connect parts of both complex and compound sentences. The expressiveness of conjunctive sentences is primarily associated with the use of conjunctions. Conjunctionless sentences, without such formal indicators of the connection between the parts of the sentence, resort to such means as intonation and modal-temporal forms of verbs. Intonation, being to a greater extent a sign of oral speech, is an expressive means and acts as a means of conveying the speech of the characters and the author of the narrative in conjunctionless complex sentences 
in the language of fiction. The absence of conjunctions in a sentence is to some extent a sign of colloquial speech and at the same time can give a special dynamism to the narrative.

\section{MATERIALS AND METHODS}

Complex sentences of the Mari language, which were largely influenced by the Russian language, are now quite well studied in terms of their classification, functioning and use. Insufficient knowledge of the stylistic possibilities and features of different types of complex sentences determines the relevance of this study. The Mari language, which had no written language until the 18th century, used simple sentences that followed one another to express complex thoughts. The presence of this fact, which served as the basis for the formation of complex sentences and the influence of the Russian language, contributed to the fact that today all types of complex sentences are represented in the Mari language. Each type of complex sentence uses a variety of expressive means. In this regard, conjunctionless complex sentences, in accordance with their structure, differ from conjunctive sentences by their unique stylistic and expressive features. The aim of the study is to determine the markers of imagery and expressiveness in the composition of conjunctionless complex sentence in comparison with conjunctive sentence. This goal is achieved by using the method of synchronous description and analysis of the collected material. The research tasks are to determine the means of expressiveness used by conjunctionless complex sentences in the language of fiction in the Mari language. The object of the research is the conjunctionless complex sentence in the language of fiction and their stylistic and expressive possibilities in comparison with the conjunctive sentence. From the point of view of language education and the formation of a language personality, the obtained results will be of great practical significance. Communication, in which a person who has language skills is able to express his thoughts vividly and figuratively, is most fully carried out with the help of complex sentences. In the modern Mari language, it is the conjunctionless complex sentence that is most suitable for expressing complex semantic relations. This article is a logical continuation of the research related to the stylistic syntax of complex sentences in the Mari language

(Sokolova, Kolyago 2019 a; 2019 б; 2020 a, 2020 b, 2020 c).

\section{DISCUSSION}

The fact that complex sentences have great artistic expressiveness is recognized by linguists and today is indisputable. The system of complex sentences in the Mari language is more characterized by a conjunctionless connection. V. T. Timofeeva (Timofeeva, 1961), E. N. Mustaev (Mustaev, 1995), and I. S. Galkin (Galkin, Mustaev, 2005) note that conjunctionless complex sentences are widely used in the Mari language.

Conjunctionless complex sentences of the Mari language, despite the lack of an indicator of the connection between the parts of the sentence, use intonation to create expressiveness. There are 4 types of intonation characteristic of conjunctionless complex sentences in the Mari language:

- Enumerative, for example: Пӧрьен-влак огыт кой, ӱдырамаш-влак ясау, ныл ий саклыме вургемыштым чиеныт. 'The men are not visible, the women are wearing clothes that they have been saving for four years' (Danilov, 2020).

Й̈̈р деч вара кушкыл-влак виян колтышт, мӧр кӱын, уржа-сорла тургым лишемеш. 'After the rain, the plants began to gain strength, strawberries ripened, the harvest is approaching' (Danilov, 2020).

- Comparative, for example: Ош лум какарга, корно шемемеш. 'The white snow darkens, the road turns black' (Chavain, 1980).

Марийже - пашаче, ватыже - йолагай. 'Husband is hardworking, wife is lazy' (Chavain, 1980).

- Conditioned, for example: Ик могырым Пӧтыр кугыза мыйым орландара, вес могырымжо ала-молан эре Митрий Иванычым шонем. 'On the one hand, Uncle Petor torments me, on the other hand, I always think about Dmitry Ivanovich' (Chavain, 1981).

Ынде Клавий ойгырымыж дене нимом ынылен ок шукто, мый тудым вӥденак нанаем. 'Now Claudia with her grief will not have time to understand anything, I will take her away by force' (Chavain, 1981).

Вольыкат вӱташте ломыжалтыш: тудат шошым шижын, тыдынат вӱташте киймыже ок шу. 'In the barn, even the cattle lowed: she also felt the spring, she does not want to lie in the barn' (Chavain, 1980).

- Interpretative, for example: Ик кечын ял мучко увер шарлыш: Илья Фомин плен гыч пӧртылын. 'One day the news spread through the village: llya Fomin returned from captivity' (Вӥдтӱрын, 2020 № 2). 
Лач Галян чонжо нигузе лыпланен огыл, «Авай» шомакым тудынат колыштмыжо шуын. 'Only Galina's heart can not calm down, she also wants to hear the word Mother' (Mikhailova, 2020 № 2).

All these types of intonation create a special rhythm of the utterance and give it dynamism and expressiveness. The absence of conjunctions, N. N. Glukhova notes, "... helps to create a special expressiveness of the text" (Glukhova, 1998).

Also, the absence of a conjunctive connection often, as N. I. Formanovskaya notes, leads to the fact that "... the structure of the parts of the sentence changes in the direction of ellipticity, incompleteness, etc. in comparison with the conjunctive sentence" (Formanovskaya, 2014).

For example, ellipticity in the conjunctionless Mari sentence can be expressed by the imperative and subjunctive moods of predicate verbs, for example: Йолташ-влак, омартан омарташкыда чонештыза: кӱшнӧ кугу лопшанге коштеш. 'Friends, fly to your hive: a large hornet is flying overhead' (Chavain, 1981).

Тыят эре яра кийман огыл: эныж погаш кае. 'You shouldn't idle: go pick raspberries Ты тоже не должен лежать без дела: иди собирай малину' (Chavain, 1981).

Пеш налам ыле - вер уке. 'I'd love to take it. but there is no place' (Chavain, 1981).

- Кеч иктаж шовыч лийже ыле, вуетым кылдена ыле. 'If you had at least a handkerchief, they would have bandaged your head' (Chavain, 1980).

Conjunctionless complex sentences in book speech often convey the speech of both the author and the participants in the narrative. The absence of conjunction and the ellipse of parts create dynamics, rhythm, and tension in conjunctionless sentence and betray it colloquial character. In conjunctionless complex sentences of the Mari language in fiction expression and emotionality are enhanced due to the intonation, the ellipse of individual elements, the use of the imperative and subjunctive mood. The absence of conjunction is the main expressive feature, in comparison with the conjunctional connection.

\section{CONCLUSION}

Syntax and its stylistic potential are important and significant elements of language education. Due to the syntax, which is the highest communicative level of the language, human speech is organized. Syntactically correctly constructed utterance allows the language personality to convey the thoughts to the interlocutor more understandable, express the opinion and argue it. Knowledge of the basics of stylistics allows you to make oral and written speech expressive and emotional. The use of complex sentences in the speech indicates the formed language competence. You can find all types of complex sentences both in oral and colloquial speech in the Mari language today. However, conjunctionless complex sentences are used more often, primarily in oral speech. Conjunctionless complex sentences are used in the author's narrative and in the speech of the characters to give the book speech ease, dynamism, and sometimes tension. On the one hand, expression is created through the use of different types of intonation. The intonation, due to the special rhythm and melody of the sentence, gives it a special expressiveness. On the other hand, imagery and expression can be created by ellipse of individual elements of conjunctionless complex sentence. It can be done by the inclusion of verb predicates in the imperative or subjunctive moods in the sentence. Conjunctionless complex sentences attract attention to the narrative by their imagery, dynamism and intensity in the language of fiction in the Mari language.

\section{ACKNOWLEDGEMENT}

This research was financially supported by RFBR and Government of the Mari El according to the research project No 19-412-120002 «Stylistic syntax of compound sentences in the Mari language»

\section{REFERENCE LIST}

Вӱдтӱрын А. (2020 № 2). Шарнымаш медаль. (Р. 113-125). Onychko, Yoshkar-Ola: Mari Book Publisher.

Galkin, I.S., Mustaev, E.N. (2005). Финно-угроведенийын негызше. Морфологий, Синтаксис, Лексике. (р. 96). Mari State University. Yoshkar-Ola.

Glukhova, N.N. (1998). Informativeness and poetics of the Mari pagan prayers. (116 p.) - Yoshkar-Ola: Mari State University. 
Danilov, M. (2020 № 6). Йыгрешке шаргӱ. (P. 10-46). Onychko, Yoshkar-Ola: Mari Book Publisher. Mustaev, E.N. (1995). Mari language. Stylistics. (168 p.). Yoshkar-Ola: Mari Book Publisher. Mikhailova, A. (2020 № 2). Канде шинча. (P. 126-129). Onychko, Yoshkar-Ola: Mari Book Publisher. Sokolova, G.L., Kolyago, A.L. (2019 a). Complex Sentences in the Mari Language. Proceedings of ADVED 2019- 5th International Conference on Advances in Education and Social Sciences. (P. 291-294). Istanbul, Turkey. .

Sokolova, G.L., Kolyago, A.L. (2019 в). Stylistic Features of the Compound Sentence in the Mari Language. Proceedings of ADVED 2019- 5th International Conference on Advances in Education and Social Sciences. (P. 295-298). Istanbul, Turkey.

Sokolova, G.L., Kolyago, A.L. (2020 a). Expressive ways of reporting other persons' spreech in the Mari language. (P. 51-54). Proceedings of INTCESS 2020-7th International Conference on Education and Social Sciences. DUBAI (UAE).

Sokolova, G.L., Kolyago, A.L. (2020 b). Knowledle of stylistic and syntactic features of complex sentences in the Mari language as a component of lanquage education (the case of parallelism). (P. 368-342). Abstracts \& Proceedings of ADVED 2020- 6th International Conference on Advances in Education. Istanbul, Turkey.

Sokolova, G.L., Kolyago, A.L. (2020 c). Language education and the evaluating principle of the expressiveness of speech in complex sentence in the Mari language (the case of syntactic figere of the period). P. 373-377. Abstracts \& Proceedings of ADVED 2020-6th International Conference on Advances in Education. Istanbul, Turkey.

Timofeeva, V.T. (1961). , Modern Mari language. Syntax of complex sentence. (152 p.). Yoshkar-Ola: Mari Book Publisher.

Chavain, S.G. (1980). Collected works in three books. 1. Poetry, prose. (318 p.). Yoshkar-Ola. Mari book publishing house.

Chavain, S.G. (1981). Collected works in three books. 1. Poetry, novel "Innet" (318 p.). Yoshkar-Ola. Mari book publishing house.

Formanovskaya, N.I. (2015). Complex sentence: Semantic and stylistic aspects, 3rd ed. (240 p.). Moscow. 